\title{
THE EFFECT OF PASTURE SUPPLEMENTED DIETS ON THE PERFORMANCE OF LACTATING EWES IN THE FOOTHILLS OF LESOTHO
}

\author{
Nchele KULEILE ${ }^{1 \times \otimes}$, Motselisi MAHLEHLA², Oluwabiyi OLUREMI², Poloko MOSEBI ${ }^{2}$, Setsumi MOLAPO², \\ Makata RANCHOBE${ }^{2}$, Leah MOEA², Lehlohonolo MOCHOA³, Mamajalle LEFOKA³, and Manchakha MANTSOE3 \\ ${ }^{1}$ Department of Animal Science, Lesotho Agricultural College, Private Bag A4, Maseru 100, Lesotho \\ ${ }^{2}$ Department of Animal Science, National University of Lesotho, P.O. Roma 180, Lesotho \\ ${ }^{3}$ Department of Agricultural Research, Ministry of Agriculture and Food Security, P.0 Box 829, Maseru 100, Lesotho \\ Email: nchelekuleile@gmail.com (D) ORCiD: 0000-0003-1848-2936 \\ Supporting Information
}

\begin{abstract}
Farmer-participatory research was implemented in the foothills of Machache Lesotho with aim to investigate the influence of supplementary feeding of ewes using forage-based diets. The study followed a randomized complete block design with four dietary treatments replicated three times. A total of 270 lactating ewes were contributed by farmers and were randomly distributed into 12 experimental units. Control treatment had a total of 54 lactating ewes made up of 18 animals per replicate while each treated groups had a total of $\mathbf{7 2}$ lactating ewes made up of 24 animals per replicate. The experiment lasted for 10 weeks. The dietary treatments were as follows; control in the form of pasture, T1: forage alone, T2: forage plus concentrate, T3: forage, concentrate and urea molasses mineral block. The treatment diet was offered in the morning before animals go to the pasture or rangeland and it was offered at the rate of 100 grams per head per day. Control animals on the other hand did not have access to supplementary feeds. Data collection on production parameters such as feed intake and live weight change was taken on weekly basis. Data on blood glucose, $\beta$-hydroxybutyric acid (BHBA), wool growth and milk quality was taken at the beginning and at the end of feeding trial. The findings indicated that the treatment group supplemented with forage, concentrates and urea mineral block performed significantly $(P<0.05)$ better than the control group in all tested parameters such as nutritive value of treatment diets, production parameters such as feed intake, live weight change and wool growth, blood parameters such as blood glucose and BHBA, and milk quality. The study also revealed (control) that pasture and forage supplementation (T1) alone do not meet the nutritional needs of lactating ewes and the animal had to use their body fat reserves to meet their maintenance needs and this was evident by loss of weight and increased blood BHBA from the two treatments.
\end{abstract}

Keywords: Concentrates, Ewe, Forage, Lactation, Molasses.

\section{INTRODUCTION}

Lactation is the period of highest demand for nutrients in sheep production cycle (Pesántez-Pacheco et al., 2019). The highest demand is as a result of nutrients needed for milk synthesis and for the maintenance of the ewe (Greiner and Wahlberg, 2005). The newly born lambs are dependent on their mother's milk for the first six weeks depending on the type of weaning practised by the farmer (Selmi et al., 2019). Milk provides essentially all the lamb's nutritional needs during the first two months (Urbano et al., 2017; Nudda et al., 2020). However, the majority of farmers lose their newly born lambs as a result of starvation due to low milk production by ewes. According to Wool and Mohair Promotion Project Appraisal Report (WAMPP, 2014), annual feed shortage during dry season is estimated at $40 \%$ in Lesotho and this has a negative bearing on ewe productivity during lactation (WAMPP, 2014). Feed shortage during dry season in Lesotho is exacerbated by farmer's habit of not planting supplementary winter forages to alleviate the inevitable good quality forage scarcity.

In Lesotho, farmers follow two lambing seasons (summer and winter) and each of them having its advantages and disadvantages in terms of feed availability. However, the end of autumn/winter lambing and its subsequent lactation period coincide with dry season which is characterised by poor quality feeds such as crop residues and stubbles that remain after harvest. These types of feeds are well known for their low nitrogen content and poor digestibility (Brand and Brundyn, 2015) and their protein content averaging 5.5\% CP and $6 \mathrm{MJ}$ ME for cereal based residues. The lactating ewe on the other hand requires metabolisable energy ranging between 10 and $12.5 \mathrm{MJ}$ ME and, 12 and $14 \%$ CP depending on the number of lambs nursing (National Research Council NRC, 1985). The nutritional gap between the basal diet and animal requirements is very high (Poppi and McLennan, 1995) and therefore requires provision of supplementary feeding to avoid the prevalent high lamb mortality and deadly metabolic disorders for lactating ewes such as ketosis (Banhero et al., 2004; Kelay and Assef, 2018). 
In an effort to promote supplementary fodder production amongst farmers, a study was executed in the Foothills agro-ecological zone of Lesotho. The aim of the study was to assess the effect of supplementary forage compared with other common sources of supplementary feeds such as concentrates and urea molasses mineral block on the performance of lactating ewes.

\section{MATERIALS AND METHODS}

\section{Study area}

An on-farm study-model which addressed the peculiarity of the local farmers who were reluctant to release their sheep to be placed on the control basal diet was conducted at Machache Foothills covering the two woolsheds namely "Machache and Bushmen". The two woolsheds falls within the Foothills of Lesotho and is situated about $40 \mathrm{~km}$ south east of the capital town Maseru. The Foothills of Lesotho are situated between 1,800 - 2,000 metres above sea level and most of its rainfall occurs from October to April (Moeletsi, 2004). Rainfall season peaks between December and February when most of the country records over $100 \mathrm{~mm}$ per month while the lowest rainfall in most localities ( $<10 \mathrm{~mm})$ occurs in June and July (Lesotho Meteorological Services, 2000; Moeletsi, 2004).

\section{Ethical approval}

The scientific and ethics committee of the Faculty of Agriculture, National University of Lesotho approved the study protocol.

\section{Experimental design}

The study followed a randomized complete block design with four dietary treatment groups made up of control (CG) and three treated groups $\left(T_{1} G, T_{2} G\right.$ and $\left.T_{3} G\right)$. Blocking was used to cater for differences in body weight of lactating sheep. Control treatment had a total of 54 lactating ewes made up of 18 animals per replicate while each treated groups had a total of $\mathbf{7 2}$ lactating ewes made up of $\mathbf{2 4}$ animals per replicate. Data was analysed using IBM Statistical Package for Social Science version 20 (IBM Corporation, 2011). Data was subjected to Analysis of Variance (ANOVA) and mean comparison test was done using Least Significant Difference (LSD).

\section{Dietary treatments}

The control treatment (CG) was pasture, and it also served as basal diet for the treated groups. The three treated groups were forage based such that treatment one was forage alone $\left(T_{1} G\right)$, treatment two was forage and concentrate in total mixed ration $\left(T_{2} G\right)$ and treatment three was similar to treatment two but with additional urea molasses mineral block $\left(T_{3} G\right)$ as presented in Table 1. Forage treatment was made up of a mixture of leguminous and cereal based forages. Concentrates treatment was made up of the mixtures of the following ingredients; sunflower, hominy chop, crushed yellow maize and maxiwol concentrate (Voermol Feed Company, Maidstone South Africa) blended together to meet requirements (\% $\mathrm{CP}$ and $\mathrm{ME}$ ) for lactating ewe. Urea molasses mineral block (UMMB) was in the form of mineral lick block. All experimental animals had access to pasture, the basal diet while, and the animals in each of $T_{1} G, T_{2} G$ and $T_{3} G$ had in addition supplementary feeds offered at the rate of $600 \mathrm{~g}$ per head per week. Urea molasses mineral block was offered on ad libitum basis when the animals were not on the pasture.

\section{Table 1 - Physical composition of the experimental diets}

\begin{tabular}{|c|c|c|c|c|}
\hline \multirow{2}{*}{ Raw Material $\quad$ (g/kg) } & \multicolumn{4}{|c|}{ Dietary Treatments } \\
\hline & CG (Grazing) & $T_{1} G$ (Forages) & $\mathrm{T}_{2} \mathrm{G}$ (Concentrates) & $T_{3} G$ (Urea molasses) \\
\hline Pasture* & Ad libitum & Ad libitum & Ad libitum & Ad libitum \\
\hline Maize stover & - & 100 & 100 & 100 \\
\hline Fodders sorghum & - & 100 & 100 & 100 \\
\hline Eragrostis teff & - & 350 & 100 & 100 \\
\hline Lucerne & - & 350 & 100 & 100 \\
\hline Grazing vetch & - & 50 & 100 & 100 \\
\hline Lab Lab & - & 50 & 100 & 100 \\
\hline Crushed yellow maize & - & - & 80 & 80 \\
\hline Sunflower seeds & - & - & 100 & 100 \\
\hline Maize hominy chop & - & - & 100 & 100 \\
\hline Maxiwol (concentrate) & - & - & 120 & 120 \\
\hline Urea Molasses block & - & - & - & Ad libitum \\
\hline Total Grams & & 1000 & 1000 & 1000 \\
\hline
\end{tabular}




\section{Animal management}

A total of $\mathbf{2 7 0}$ lactating sheep obtained from native farmers were used in this trial to collect data on growth indices while, 10 animals per replicate with a total of 120 animals were used to obtain samples for blood and milk, and to collect the wool parameters. All experimental animals were identified using plastic tags and were managed according to individual farmer's style. Animals were fed supplementary diets in the morning before going to the grazing area. Animals were given ad-libitum access to water. The feeding trial lasted for ten weeks after lambing plus one week of adaptation period. A total of $\mathbf{2 7}$ farmers participated in the study by offering their animals as well as helping with data collection.

\section{Data collection}

\section{Nutrient profile of experimental diets}

The nutrient content of the basal diet and supplementary feeds were determined according to AOAC (1990). Feed samples were thus subjected to proximate analysis to determine dry matter (DM), ash, crude protein (CP), crude fibre (CF). Macro minerals namely phosphorus and calcium were determined using atomic absorption spectroscopy. Metabolisable energy (ME), rumen undegradable protein (RUP) and total digestible nutrients (TDN) were estimated using Nutrimix Professional Animal Feed Formulation Software.

\section{Production parameters}

\section{Growth performance}

Data on feed intake and body weight gain were collected on weekly basis. Weighing scales were used to measure body weight and feeds. Feed intake was estimated as the amount of feed offered less the unconsumed.

\section{Blood indices}

Blood samples were collected from the jugular vein using sterilised needle and syringe at the beginning and at the end of feeding trial to determine blood glucose and $\beta$-hydroxybutyric acid (BHBA). Blood samples were directly put on the recommended blood strips for blood glucose and BHBA determinations and the readings were taken using Freestyle blood meter.

\section{Wool indices}

Wool growth rate was determined by measuring its length at the beginning of feeding trial and at the end of feeding trial using a measuring ruler. The total length was divided by ten weeks (experimental duration) in order to determine growth rate per week.

\section{Milk quality}

Milk samples were collected three times during the trial and the collections were done at the beginning of lactation, mid lactation (end of week five) and at the end of lactation (week ten). Milk samples were collected in the morning by hand milking of each ewe and using small milk vials $(200 \mathrm{ml})$ for collection. The morning samples were kept refrigerated at $4^{\circ} \mathrm{C}$, and were taken to the laboratory for analysis. A rapid milk test was conducted using Milkana Multi Test equipment which provided a list of parameters $(\mathrm{pH}$, water content, milk fat, protein, lactose and solids non-fat) that were determined per sample.

\section{RESULTS AND DISCUSSION}

\section{Proximate composition of experimental diets}

The nutrient composition of the experimental diets is presented in Table 2. The result revealed that the supplementary feeds were significantly $(p<0.05)$ better than the pasture based control diet in CP, ME, TDN, RUP, Ca and $P$. The nutrient density of CP, ME, TDN, RUP, Ca and $P$ between the treated group also improved significantly $(p<0.05)$ from $T_{1} G$ to $T_{3} G$. The crude fibre content of the control and $T_{1} G$ was significantly $(p<0.05)$ higher than that of $T_{2} G$ and $T_{3} G$ and this can affect the utilization and metabolisability of these diets. The lowest crude protein value of $8.4 \%$ in the control diet was adequate to meet the minimum requirements for microbial protein synthesis and maintenance of ewe put at $7 \% \mathrm{CP}$ (Gebeyew et al., 2015). However, this value was lower than the minimum requirements for lactating ewes nursing single and twin lambs. The $\mathrm{T}_{1} \mathrm{G}$ crude protein content was also lower than the requirement for lactating ewe estimated between 12 and 14\% CP (National Research Council NRC, 1985). The overall low nutritive value and high crude fibre content of forage diet $\left(T_{1} G\right)$ implied that it will not support the high nutritional needs of lactating ewes unless some form of supplementary feed is offered.

\section{Sheep growth performance}

The effect of supplementary feeding on sheep performance is shown in Table 3. The result showed that the dietary treatments had a significant $(p<0.05)$ influence on protein intake and live weight change. Animals fed the control and $T_{1} G$ (forage alone) diets had the lowest protein intake and they also lost weight during the feeding trial. The loss in weight was in the range of 0.80 to $1.3 \mathrm{~kg}$ which translates to between $3.7 \%$ and $2.23 \%$, respectively. This result portrays that the rangeland in Lesotho is not very bad when compared to other regions where Brand and Brundyn (2015) and Bushara et al. (2018) observed a weight loss as high as $10 \%$ of body weight. Animals fed diets $T_{2} G$ and $T_{3} G$ which were mixtures of forage and concentrate maintained their body weight during this critical production phase associated with weight loss. 
The poor performance of animals fed control diet could be associated with low dry matter yield of pastures during spring and early summer because pastures were in their worst condition with little grass cover. The condition could also have been exacerbated by long spell of drought which was experienced in Lesotho during this period as well. Under the prevailing conditions animals had to spend a lot of energy in movement from homestead in search of pasture land most of the time, as well as travel to drinking points due to the drying up of nearby water sources like streams on account of the severe drought. The animals in the control group were at higher risk as evident by the results where animals lost weight by as much as $3.7 \%$. The result of the current study are in contrast to the findings of Brand and Brundyn (2015) who observed no significant $(p>0.05)$ difference between supplemented and non-supplemented sheep in live weight change. The difference could have been due to difference in basal diet which was wheat stubble in their study and their animals were able to meet their dry matter intake. Pedernera et al. (2018) reported similar results which showed significant differences in live weight changes between the animals in the control and supplemented diet groups where about $3.31 \mathrm{~kg}$ was lost during 4 weeks of gestation.

\section{Table 2 - Nutrient composition of experimental diets (\%)}

\begin{tabular}{|c|c|c|c|c|c|c|}
\hline \multirow{2}{*}{ Parameters } & \multicolumn{4}{|c|}{ Experimental diets } & \multicolumn{2}{|c|}{ Significance } \\
\hline & $\mathbf{C G}$ & $\mathbf{T}_{1} \mathbf{G}$ & $\mathbf{T}_{\mathbf{2}} \mathbf{G}$ & $T_{3} G$ & $\mathbf{P}$ & CV \\
\hline Crude protein & $8.40^{a}$ & $11.00^{b}$ & $14.00^{c}$ & 16. $00^{c}$ & 0.001 & 1.23 \\
\hline ME (kcal) & $1890.00^{a}$ & $2108.00^{b}$ & $3298.00^{c}$ & 3641. $00^{c}$ & 0.001 & 4.35 \\
\hline TDN & $49.00^{a}$ & $60.00^{b}$ & $79.00^{c}$ & $84.00^{d}$ & 0.001 & 1.08 \\
\hline Crude fibre & $30.00^{a}$ & $33.00^{a}$ & 19. $00^{b}$ & $20.00^{b}$ & 0.001 & 2.66 \\
\hline RUP & $0.700^{a}$ & $1.30^{b}$ & $3.79 c$ & $4.10^{c}$ & 0.001 & 12.11 \\
\hline $\mathrm{Ca}$ & $0.50^{a}$ & $1.24^{b}$ & $2.35^{c}$ & $2.56^{c}$ & 0.001 & 8.01 \\
\hline $\mathbf{P}$ & $0.36 \mathrm{a}$ & $0.63^{b}$ & $0.79 c$ & $0.86^{c}$ & 0.001 & 15.37 \\
\hline
\end{tabular}

$\mathrm{a}, \mathrm{b}, \mathrm{c}, \mathrm{d}$ Means in the same row with different superscripts differ significantly $(\mathrm{p}<0.05)$; $\mathrm{P}=\mathrm{Probability}$ at $0.05 \%$; CV $=\mathrm{Coefficient}$ of variation; CG = Control; $T_{1} G=$ Forages; $T_{2} G=$ Forages + concentrates; $T_{3} G=$ Forage + Concentrates + Urea molasses mineral block; ME = Metabolisable energy; RUP = Rumen undegradable protein; TDN= Total Digestible Nutrients

\section{Table 3 - The effect of experimental diets on the performance of lactating ewes}

\begin{tabular}{|c|c|c|c|c|c|c|}
\hline \multirow{2}{*}{ Parameters } & \multicolumn{4}{|c|}{ Experimental diets } & \multicolumn{2}{|c|}{ Significance } \\
\hline & CG & $T_{1} G$ & $\mathbf{T}_{\mathbf{2}} \mathbf{G}$ & $\mathbf{T}_{3} \mathbf{G}$ & $\mathbf{P}$ & CV \\
\hline Initial BW (kg) & 36.2 & 35.9 & 36.7 & 36 & 0.122 & 1.01 \\
\hline Final BW(kg) & $34.9^{a}$ & $35.1^{\mathrm{ab}}$ & $37.3^{\mathrm{ab}}$ & $37.4^{b}$ & 0.001 & 1.43 \\
\hline Protein intake (grams) & $70^{a}$ & $110^{b}$ & $140^{c}$ & $160^{c}$ & 0.001 & 1.23 \\
\hline Live weight change (kg) & $-1.3^{a}$ & $-0.8^{b}$ & $+0.6^{c}$ & $+1.4^{d}$ & 0.001 & 2.56 \\
\hline Live weight change (\%) & $-3,7^{a}$ & $-2.23^{b}$ & $+1.61^{c}$ & $+3.74^{d}$ & 0.001 & 2.08 \\
\hline
\end{tabular}

$a, b, c, d$ Means in the same row with different superscripts differ significantly $(p<0.05)$; $P=$ Probability at $0.05 \%$; $C V=$ Coefficient of variation; CG $=$ Control; $T_{1} G=$ Forages; $T_{2} G=$ Forages + concentrates; $T_{3} G=$ Forage + Concentrates + Urea molasses mineral block

\section{Blood glucose}

The blood glucose result of the lactating ewes (Table 4) indicated that there was significant $(P<0.05)$ difference amongst the treatments. The control animals had the lowest blood glucose while, the animals in both the control and $T_{1} G$ groups showed a negative blood glucose response. Animals in $T_{2} G$ and $T_{3} G$ had increased blood glucose level. Despite this observation blood glucose during the entire experimental period was within the normal glucose range according to Kaneko et al. (2008) who provided reference range values for glucose as 50.09 to $80.0 \mathrm{mg} \mathrm{dL}^{-1}$. The findings of the current study are in agreement with the findings of Pedernera et al. $(2018)$ who observed significant $(P<0.05)$ difference between blood glucose of supplemented group $(66 \mathrm{mg} / \mathrm{dL})$ and the control $(44 \mathrm{mg} / \mathrm{dL})$. The comparatively low blood glucose in the current study for the control and $T_{1} G$ was an indicator that the sheep were unable to meet their nutritional needs for energy and hence were in a negative energy balance. Chilliard et al. (2000) and Duehlmeier et al. (2011) reported that a decrease in blood glucose concentrations could lead to lipid mobilization, which is reflected by high concentration of NEFA, which are mobilized in the liver as an alternate energy source. Blood metabolic profile is an important laboratory diagnostic technique that can be used to assess the nutritional status and animal health efficiently (Herdt et al., 2000). This information is very crucial to guarantee the metabolic and nutritional needs of ewes during the early lactation to reduce the mortality rates of new-borns and, consequently economic loss.

\section{Blood $\beta$-hydroxybutyric acid (BHBA)}

The effect of supplementary feeding on sheep blood $\beta$-hydroxybutyric acid (BHBA) results is shown in Table 5 . The dietary factors had a significant $(P<0.05)$ influence on the BHBA response whereby the control group had the highest 
blood BHBA than the supplemented groups. The BHBA values were within the range associated with subclinical ketosis. Threshold blood BHBA in sheep with subclinical ketosis is variable and it ranges between $0.5 \mathrm{mmol} / \mathrm{l}$ to $1.6 \mathrm{mmol} / \mathrm{I}$ (Balikci et al., 2009; Feijó et al., 2015) while, in sheep with clinical ketosis it ranges from $1.6 \mathrm{mmol} / \mathrm{I}$ to $7 \mathrm{mmol} / \mathrm{I}$ (Lacetera et al., 2002; Balikci et al., 2009). Panousis et al. (2012) reported higher BHBA levels in sheep with pregnancy toxaemia as compared to lactating sheep. The blood BHBA of the supplemented dietary groups with the exception of $\mathrm{T}_{1} \mathrm{G}$ had lower BHBA values indicating that the animals did not experience negative energy balance.

\section{Wool growth}

Wool growth rates result (Table 6) clearly showed the importance of supplementary feeding in wool growth. Animals that were offered supplementary feeds had significantly $(P<0.05)$ wool growth rate $(267.3$ micron/day to 398.0 microns/day) than the control animals (214.3 microns/day). However there were no significant $(P>0.05)$ differences in wool growth percentage amongst the supplemented animals. The differences in wool growth rate between supplemented and control revealed a range of 6 to $8 \%$ higher in favour of the animals on feed supplementation and $T_{3} G$ was highest. This result is comparable to the findings of White et al. (2001) who reported $8 \%$ higher wool growth for supplemented sheep than the control. The control group which had the lowest wool growth was also the lowest in crude protein, metabolisable energy and rumen (RUP) undegradable protein. Wool growth rate partly depends on the quality and quantity of protein which is influenced by amino acid profile. Sulphur containing amino acids cysteine and methionine as well as lysine are precursors for wool growth. Abdollahzadeh and Yousefi (2013) reported that by pass protein (RUP) increases wool growth. These researchers also indicated that optimum energy level is required for synthesis of wool in the presence of amino acids.

\section{Table 4 - Effect of the experimental diets on blood glucose of lactating ewes}

\begin{tabular}{lcccc|cc} 
& \multicolumn{3}{c}{ Experimental diets } & \multicolumn{2}{c}{ Significance } \\
\cline { 2 - 7 } Parameters & CG & $\mathrm{T}_{1} \mathrm{G}$ & $\mathrm{T}_{2} \mathrm{G}$ & $\mathrm{T}_{3} \mathrm{G}$ & $\mathrm{P}$ & $\mathrm{CV}$ \\
\hline Initial blood glucose $\left(\mathrm{mg} \mathrm{dL}^{-1}\right)$ & 54.6 & 55 & 55 & 54 & 0.215 & 2.66 \\
Final blood glucose $\left(\mathrm{mg} \mathrm{dL}^{-1}\right)$ & $52.2^{\mathrm{a}}$ & $54.8^{\mathrm{a}}$ & $60^{\mathrm{b}}$ & $64.4^{\mathrm{b}}$ & 0.001 & 3.37 \\
Blood glucose response & $-2.4^{\mathrm{a}}$ & $-0.2^{\mathrm{b}}$ & $+5.0^{\mathrm{c}}$ & $+_{10.4^{\mathrm{d}}}$ & 0.001 & 3.71 \\
\hline
\end{tabular}

a, b,c,dMeans in the same row with different superscripts differ significantly $(p<0.05), P=$ Probability at $0.05 \%$; CV $=$ Coefficient of variation, CG $=$ Control, $\mathrm{T}_{1} \mathrm{G}=$ Forages, $\mathrm{T}_{2} \mathrm{G}=$ Forages + concentrates, $\mathrm{T}_{3} \mathrm{G}=$ Forage + Concentrates + Urea molasses mineral block

\section{Table 5 - Effect of experimental diets on $\beta$-hydroxybutyric acid (BHBA) of lactating ewes}

\begin{tabular}{lcccccc} 
Parameters & \multicolumn{3}{c|}{ Experimental diets } & \multicolumn{2}{c}{ Significance } \\
\cline { 2 - 6 } & CG & $\mathrm{T}_{1} \mathrm{G}$ & $\mathrm{T}_{2} \mathrm{G}$ & $\mathrm{T}_{3} \mathrm{G}$ & $\mathbf{P}$ & $\mathbf{C V}$ \\
\hline Initial blood BHBA $\left(\mathrm{mg} \mathrm{dL}^{-1}\right)$ & 0.49 & 0.50 & 0.51 & 0.50 & 0.117 & 2.66 \\
Final blood BHBA $\left(\mathrm{mg} \mathrm{dL}^{-1}\right)$ & $0.70^{\mathrm{a}}$ & $0.62^{\mathrm{a}}$ & $0.43^{\mathrm{b}}$ & $0.25^{\mathrm{c}}$ & 0.001 & 2.34 \\
BHBA response & $+0.21^{\mathrm{a}}$ & $+0.12^{\mathrm{b}}$ & $-0.08^{\mathrm{c}}$ & $-0.25^{\mathrm{d}}$ & 0.001 & 3.71
\end{tabular}

$a, b, c, d$ Means in the same row with different superscripts differ significantly $(p<0.05), P=$ Probability at $0.05 \% ; C V=$ Coefficient of variation, $C G$ $=$ Control; $\mathrm{T}_{1} \mathrm{G}=$ Forages; $\mathrm{T}_{2} \mathrm{G}=$ Forages + concentrates; $\mathrm{T}_{3} \mathrm{G}=$ Forage + Concentrates + Urea molasses mineral block

Table 6 - The effect of experimental diets on wool growth

\begin{tabular}{|c|c|c|c|c|c|c|}
\hline \multirow{2}{*}{ Parameters } & \multicolumn{4}{|c|}{ Experimental diets } & \multicolumn{2}{|c|}{ Significance } \\
\hline & CG & $T_{1} G$ & $T_{2} G$ & $T_{3} G$ & $\mathbf{P}$ & CV \\
\hline Initial length (mm) & 16.5 & 14.2 & 15.7 & 15.5 & 0.191 & 1.03 \\
\hline Final Length(mm) & $27^{a}$ & $27.3^{a}$ & $30.5^{b}$ & $35^{b}$ & 0.001 & 2.88 \\
\hline Growth rate (microns/day) & $214.3^{a}$ & $267.3^{b}$ & $302.0^{c}$ & $398.0^{d}$ & 0.001 & 7.66 \\
\hline Wool growth rate (\%) & $38.8^{a}$ & $46.8^{b}$ & $45^{b}$ & $46.1^{b}$ & 0.001 & 2.03 \\
\hline
\end{tabular}

\section{Milk quality}

The effect of supplementary feeding on milk quality of lactating ewes is in Table 7. The result indicated that provision of supplementary feeds to lactating sheep resulted in a significant $(P<0.05)$ improvement in milk composition for the lambs. The milk composition for supplemented sheep was superior to control sheep in all parameters measured; butterfat, protein, SNF, lactose and density. Within the treated groups ewes in $T_{3} G$ were better than animals in $T_{2} G$ and $T_{1} G$ in terms of protein, SNF and density. Ewes fed forage treatment $T_{1} G$ were better in milk butterfat than any other treatment. These results are in agreement with the findings of Obeidat et al. (2019) who reported high protein content 
and SNF for supplemented ewes than the control group offered no supplementary feeds. The butterfat of $T_{1} G$ was the highest, probably because this diet had relatively larger particle size than all the other experimental diets and therefore conformed to the fact that feeding of finely ground forages inadequately stimulates rumination and lowers saliva production. This results in a rumen fermentation pattern that produces a higher proportion of propionic acid and, in turn, reduces milk fat percentage (Stokes et al., 2018). On the other hand $T_{3} G$ was superior in milk protein, SNF, lactose and milk density, the findings can be interpreted relative to nutritive value of dietary treatments whereby $T_{3} G$ had the highest rumen undegradable protein (RUP) and metabolisable energy and the two components contribute significantly to gluconeogenesis (Cronje, 1990) that contributes to high lactose, SNF and milk density.

\section{Table 7 - The effect of experimental diets on milk quality of lactating ewes}

\begin{tabular}{|c|c|c|c|c|c|c|}
\hline \multirow{2}{*}{ Parameters } & \multicolumn{4}{|c|}{ Experimental diets } & \multicolumn{2}{|c|}{ Significance } \\
\hline & CG & $T_{1} G$ & $\mathbf{T}_{2} \mathbf{G}$ & $T_{3} G$ & $\mathbf{P}$ & CV \\
\hline Butterfat (\%) & $5.44^{a}$ & $9.90^{b}$ & $8.05^{c}$ & $8.76^{d}$ & 0.001 & 24.10 \\
\hline Proteins (\%) & $3.46^{a}$ & $4.61^{b}$ & $5.05^{b c}$ & $5.75^{c}$ & 0.001 & 17.87 \\
\hline SNF (\%) & $8.21^{a}$ & $9.67^{b}$ & $10.18^{b}$ & $11.03^{b}$ & 0.001 & 10.83 \\
\hline Lactose (\%) & $4.08^{a}$ & $4.28^{b}$ & $4.36 b^{c}$ & $4.46^{c}$ & 0.001 & 3.26 \\
\hline
\end{tabular}

\section{CONCLUSION}

The results obtained in this study revealed that pasture alone as basal diet and/or in combination with forages both cereal and legumes cannot meet the nutritional needs of lactating ewes from the proxy indicators for nutritional status namely loss of weight, low blood glucose and high blood $\beta$-hydroxybutyric acid (BHBA). Production indicators were also very low for ewes on pastures and/or in combination with cereal and legume forage because the ewes under these treatments experienced low wool growth rates and milk with low nutritive value for lambs. The use of forage and concentrate mixture in total mixed ration coupled with urea molasses mineral block proved to be adequate for lactating ewes because animals were able to maintain and improve their body weight during the critical phase, and it is recommended for lactating ewes during dry periods when dry matter yield in rangelands and pastures are and pastures are low. Animals also had better production in terms of wool growth and milk composition.

\section{DECLARATIONS}

\section{Acknowledgements}

The research team wishes to thank the Wool and Mohair Promotion Project (WAMPP) for providing the financial support for research, the Department of Animal Science, the National University of Lesotho, Roma, Lesotho for provision of logistics, the Ministry of Agriculture and Food Security, Lesotho for allowing its staff to participate in the shared research, Thanks to research assistants who work tirelessly during data collection.

\section{Authors' contributions}

Prof. Oluremi was the study leader and he approved the study and moderated the write-up; Kuleile designed the study and drafted the manuscript; Mosebi participated in the design of the study and was responsible for fodder production; Mahlehla was the overall supervisor of data collection and she worked with postgraduate students to plan and execute activities of the trial; Lefoka, Mantsoe and Mochoa supervised data collection and play vital role in the selection of farmers. Postgraduate students (Moea and Ranchobe) were responsible for day to day running of the trial, data collection and arranging data in excel and statistical tools.

\section{Conflict of interest}

Animal nutrition team that carried out the study reported no conflict of interest.

\section{REFERENCES}

Abdollahzadeh F and Yousefi S (2013). Preliminary Study on the factors Affecting growth and Properties of Mohair and Wool fibers. Bulletin of Environment, Pharmacology and Life Sciences, 2 (12): 117-121. Link: http://bepls.com/nov_2013/18\%20November2013\%20BEPLS.pdf

Association of Official Analytical Chemists AOAC (1990). Official Methods of Analysis. Volume 1. 15th Edition, Virginia, USA. pp 69-88. ISBN 0935584-42-0.

Balikci E, Yildiz A and Gurdogan F (2009). Investigation on some biochemical and clinical parameters for pregnancy toxemia in Akkaraman ewes. Journal of Animal and Veterinary Advances, 8 (7):1268-1273. Link: https://www.cabdirect.org/cabdirect/abstract/20093140003 
Banhero GE, Quintans G, Martin GB, Lindsay DR, and Milton JTB (2004). Nutrition and colostrum production in sheep. 1. Metabolic and hormonal responses to a high-energy supplement in the final stages of pregnancy. Reproduction, Fertility and Development, 16(6): 633-643. DOI: https://doi.org/10.1071/RD03091

Brand TS and Brundyn L (2015).Effect of supplementary feeding to ewes and suckling lambs on ewe and lamb live weights while grazing wheat stubble. South African Journal of Animal Science 45(1): 89-95. DOI: http://dx.doi.org/10.4314/sajas.v45i1.11

Bushara I, Fathia G and Godah I (2018). Effect of supplementary feeding with residual of sesame capsule to lactating desert goat during dry period in north kordofan state, Sudan. Advances in Biology \& Earth Sciences 3(1): 47-59. Link: http://jomardpublishing.com/UploadFiles/Files/journals/ABES/V3N1/Busharal.pdf

Chilliard Y, Ferlay A, Faulconnier Y, Bonnet M, Rouel J and Bocquier F (2000). Adipose tissue metabolism and its role in adaptations to under nutrition in ruminants. Proceedings of Nutrition Society, 59(1):127-134. DOI: https://doi.org/10.1017/S002966510000015X

Cronje PB (1990). Supplementary feeding in ruminants-A physiological approach. South African Journal of Animal Science, 20(3): 110-117. Link: https://www.ajol.info/index.php/sajas/article/view/138858/128531

Duehlmeier R, Fluegge I,Schwert B, Parvizi N and Ganter M (2011). Metabolic adaptations to pregnancy and lactation in German Blackheaded Mutton and Finn sheep ewes with different susceptibilities to pregnancy toxaemia. Small Ruminant Research, 96(2-3):178-184. D0I: https://doi.org/10.1016/j.smallrumres.2010.12.002

Feijó JO, Schneider A, Schmitt E, Brauner CC, Martins CF, Barbosa-Ferreira M, Del Pino FA, Faria B, Junior SP, Rabassa, VR and Corrêa MN (2015). Prepartum administration of recombinant bovine somatotropin (rBST) on adaptation to subclinical ketosis of the ewes and performance of the lambs. Brazilian Journal of Veterinary and Animal Science, 67(1): 103-108. DOI: https://doi.org/10.1590/1678-6849

Gebeyew K, Animut G, Urge M and Feyera T (2015). The effect of feeding dried tomato pomace and concentrate on nutritional and growth parameters of Hararghe Highland Sheep, Eastern Ethiopia. Journal of Advance in Dairy Research, 3(1):130. D0I: https://doi.org/10.4172/2329-888X.1000130

Greiner AP and Wahlberg ML (2005).Management and Nutrition of the Lactating Ewe and Young Lambs. Virginia Cooperative Extension. Virginia State University, USA. Link: http://sites.ext.vt.edu/newsletter-archive/

Herdt TH, Rumbeiha W, and Braselton WE (2000). The use of blood analyses to evaluate mineral status in livestock. Veterinary Clinics of North America Food Animal Practice, 16(3): 423-444. DOI: https://doi.org/10.1016/S0749-0720(15)30078-5

IBM Corporation (2011) IBM SPSS Statistics for Windows, Version 20.0. Armonk, New York.

Kaneko JJ, Harvey JW, Bruss ML (2008). Clinical Biochemistry of Domestic Animals. 6 ${ }^{\text {th }}$ Edn., Elsevier Academic Press, Amsterdam. ISBN-13: 9780123704917. Link: https://www.elsevier.com/books/clinical-biochemistry-of-domestic-animals/kaneko/978-0-12-370491-7

Kelay A and Assef A (2017) Causes, Control and Prevention Methods of Pregnancy Toxemia in Ewe: A Review. Journal of Life Science and Biomedicine, 8(4): 69-76. Link: https://jlsb.science-line.com/attachments/article/62/J.\%20Life\%20Sci.\%20Biomed.\%208(4)\%206976,\%202018.pdf

Lacetera N, Franci O, Scalia D, Bernabucci U, Ronchi B, and Nardone A (2002). Effects of nonesterified fatty acids and BHB on functions of mononuclear cells obtained from ewes. American Journal of Veterinary Research, 63(3): 414-418. Doi: https://doi.org/10.2460/ajvr.2002.63.414

Lesotho Meteorological Services LMS (2000) Lesotho national report on climate change. Ch. 7, pp 23-25.

Moeletsi ME (2004) Agroclimatic characterization of Lesotho for dryland maize production. MSc thesis, Department of Soil, Crop and Climate Sciences, University of Free State, Bloemfontein, South Africa. Pp. 176

National Research Council NRC (1985). Nutrient requirements of sheep, 6th Revised Edition.National Academy Press, Washington, D.C.

Nudda A, Atzori AS, Correddu F, Battacone G, Lunesu MF, Cannas A, and Pulina G (2020). Effects of nutrition on main components of sheep milk. Small Ruminant Research, 184: 106015. Doi: https://doi.org/10.1016/j.smallrumres.2019.11.001

Obeidat BS, Kridli RT, Mahmoud KZ, Obeidat MD, Haddad SG, Subih HS, Ata M, Al-JamalAE, Ghazal TA and Al-Khazaleh AM (2019). Replacing soybean meal with sesame meal in diets of lactating Awassi ewe suckling single lambs, nutrient digestibility, milk production and lamb growth. Animals, 9(4): 157. DOI: https://doi.org/10.3390/ani9040157

Panousis N, Brozos C, Karagiannis I, Giadinis ND, Lafi, S and Kritsepi-Konstantinou M (2012). Evaluation of precision xceed meter for on-site monitoring of blood $\beta$-hydroxybutyric acid and glucose concentrations in dairy sheep. Research of Veterinary Science, 93(1): 435-439. DOI: https://doi.org/10.1016/j.rvsc.2011.06.019

Pedernera M, Pérez-Sánchez,LA, Romero-Aguilar LD, Aguirre V, Flores-Pérez I, Vázquez R and Orihuela A (2018). Effects of high concentrate supplementation of Saint Croix sheep during peripartum on neonatal lamb behaviour. Journal of Applied Animal Research, 46(1):720-724. DOI: https://doi.org/10.1080/09712119.2017.1388242

Pesántez-Pacheco JL, Heras-Molina A, Torres-Rovira L, Sanz-Fernández MV, García-Contreras C, Vázquez-Gómez M, and Astiz S (2019). Maternal metabolic demands caused by pregnancy and lactation: association with productivity and offspring phenotype in high-yielding dairy ewes. Animals, 9(6): 295. Doi: https://doi.org/10.3390/ani9060295

Poppi DP, and McLennan SR (1995). Protein and energy utilization by ruminants at pasture. Journal of Animal Science, 73(1): 278-290. Doi: https://doi.org/10.2527/1995.731278x

Selmi H, Bahri A and Rouissi H (2019). Nutrition for Lactation of Dairy Sheep, Lactation in Farm Animals-Biology, Physiological Basis, Nutritional Requirements, and Modelization, Naceur M'Hamdi, Intech Open publication, Croatia. DOI: https://doi.org/10.5772/intechopen.85344

Stokes SR, Waldner DN, Jordan ER and Looper ML (2018). Managing milk composition: maximizing rumen function.Texas AM Agri Life extension.L5389/12/00.https://cdnext.agnet.tamu.edu/wpcontent/uploads/2018/12/EL-5389-managing-milk-composition-maximizingrumen-function.pdf

Urbano SA, De Andrade Ferreira M, Do Nascimento Rangel AH, De Lima Júnior DM, De Andrade RDPX, and Novaes LP (2017). Lamb feeding strategies during the pre-weaning period in intensive meat production systems. Tropical and Subtropical Agroecosystems, 20(1): 49-63. https://www.revista.ccba.uady.mx/ojs/index.php/TSA/article/view/2242

Waterman R and Butler R (2010). Metabolic signals of the beef cows in negative energy balance. In 'Proceedings of the 4th grazing livestock nutrition conference'. (Eds BW Hess, T Del Curto, JGP Bowman, RC Waterman). pp. 91-101. (Western Section -American Society of Animal Science: Champaign, IL)

White LC, Tabe LM, Dove H and Hambli J (2001). Increased efficiency of wool growth and live weight gain in Merino sheep fed transgenic lupin seed containing sunflower albumin. Journal of the Science of Food and Agriculture, 81(1): 147-154. DOI: https://doi.org/10.1002/10970010(20010101)81

Wool and Mohair Promotion Project: WAMPP (2014). Final project design report .Appendix 4: Detailed project description. Pp. 74. 